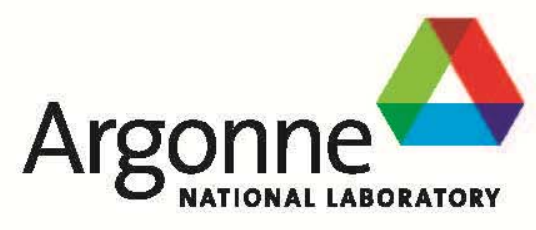

ANL/CSE-14/26

\title{
Dissolution of Sintered Mo Disks
}

Chemical Sciences and Engineering Division 


\begin{abstract}
About Argonne National Laboratory
Argonne is a U.S. Department of Energy laboratory managed by UChicago Argonne, LLC under contract DE-AC02-06CH11357. The Laboratory's main facility is outside Chicago, at 9700 South Cass Avenue, Argonne, Illinois 60439. For information about Argonne

and its pioneering science and technology programs, see www.anl.gov.
\end{abstract}

\title{
DOCUMENT AVAILABILITY
}

Online Access: U.S. Department of Energy (DOE) reports produced after 1991 and a growing number of pre-1991 documents are available free via DOE's SciTech Connect (http://Www.osti.gov/scitech/).

Reports not in digital format may be purchased by the public from the National Technical Information Service (NTIS):

U.S. Department of Commerce

National Technical Information Service

5301 Shawnee Rd

Alexandria, VA 22312

unw.ntis.gov

Phone: (800) 553-NTIS (6847) or (703) 605-6000

Fax: (703) 605-6900

Email: orders@ntis.gov

Reports not in digital format are available to DOE and DOE contractors from the Office of Scientific and Technical Information (OST):

U.S. Department of Energy

Office of Scientific and Technical Information

P.O. Box 62

Oak Ridge, TN 37831-0062

unw.osti.gov

Phone: (865) 576-8401

Fax: (865) 576-5728

Email: reports@osti.gov

\section{Disclaimer}

This report was prepared as an account of work sponsored by an agency of the United States Government. Neither the United States Government nor any agency thereof, nor UChicago Argonne, LLC, nor any of their employees or officers, makes any warranty, express or implied, or assumes any legal liability or responsibility for the accuracy, completeness, or usefulness of any information, apparatus, product, or process disclosed, or represents that its use would not infringe privately owned rights. Reference herein to any specific commercial product, process, or service by trade name, trademark, manufacturer, or otherwise, does not necessarily constitute or imply its endorsement, recommendation, or favoring by the United States Government or any agency thereof. The views and opinions of document authors expressed herein do not necessarily state or reflect those of the United States Government or any agency thereof, Argonne National Laboratory, or UChicago Argonne, LLC. 


\section{Dissolution of Sintered Mo Disks}

by

Peter Tkac and George F. Vandegrift

Chemical Sciences and Engineering Division, Argonne National Laboratory

prepared for

U.S. Department of Energy, National Nuclear Security Administration,

Office of Defense Nuclear Nonproliferation

September 2014 



\section{CONTENTS}

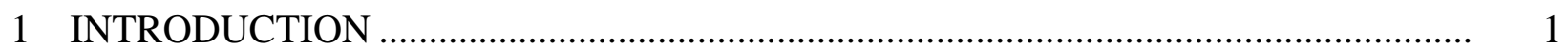

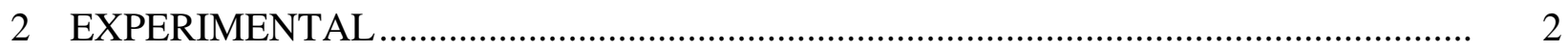

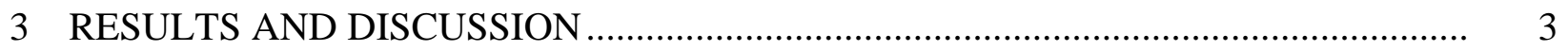

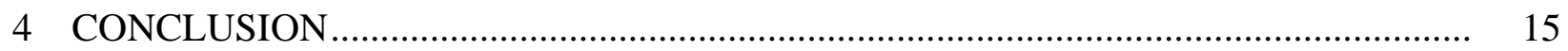

\section{FIGURES}

1 SEM Images of As-Received Mo-100 Enriched Powder and Recycled Mo-100 Enriched Powder

2 Dissolution Rates of Mo-100 Disks Sintered at $1500^{\circ} \mathrm{C}$ versus Open Porosity ........... 6

3 Dissolution Rates of NPA Mo Disks versus Open Porosity …………………............... 8

4 SEM Images of Mo Powder Obtained after the Reduction of Recycled ANL\#80

$\mathrm{MoO}_{3}$ Powder and Commercial NPA Mo Powder …………………………………... 8

5 Effect of Sintering Temperature and Pressing on Open Porosity of Disks Made from Recycled ANL\#80 $\mathrm{MoO}_{3}$ Powder...................................................................... 10

$6 \quad$ SEM Images of Sintered Disks Fracture and Starting Powders for NPA and PM Disks

$7 \quad$ Temperature Profile during the Dissolution of PM Mo Disks........................................ 12

8 SEM Images of As-received Commercial NPA Powder and Reduced Small Batch of ANL Recycled $\mathrm{MoO}_{3}$ Powder

9 Photograph of Disk \#90 Made from ANL-Recycled $\mathrm{MoO}_{3}$ Powder and NPA Disk \#92. 


\section{TABLES}

1 Characteristics of Sintered Mo-100 Enriched Disks and Corresponding

Dissolution Rates

2 Characteristics of Sintered Mo-100 Enriched Disks and Corresponding

Dissolution Rates

3 Characteristics of Mo Disks from Recycled ANL\#80 $\mathrm{MoO}_{3}$ and Corresponding

Dissolution Rates

4 Characteristics of Sintered Mo Disks Made from Commercial PMA Spray-Dried

Mo Spheres and Corresponding Dissolution Rates .....

5 Characteristics of Sintered Mo Disks Made from Recycled $\mathrm{MoO}_{3}$ Powder and Commercial NPA Powder. 


\section{DISSOLUTION OF SINTERED MO DISKS}

\section{INTRODUCTION}

Argonne National Laboratory (ANL), in cooperation with Oak Ridge National Laboratory (ORNL) and NorthStar Medical Technologies, LLC (NorthStar), is working on optimization of production of sintered Mo disks. Sintered Mo disks can be used for production of Mo-99 by two paths: the Mo-100( $\gamma, n)$ Mo-99 reaction or neutron capture with Mo-98 enriched or natural Mo targets using the Mo-98(n, $\gamma$ ) reaction. Irradiated Mo targets are then dissolved in hydrogen peroxide and converted to $\mathrm{K}_{2} \mathrm{MoO}_{4}$ in $5 \mathrm{M} \mathrm{KOH}$ to be loaded onto the RadioGenix ${ }^{\mathrm{TM}}$ generator to separate Tc-99m from Mo for medical applications. To make the production of Mo-99 cost-effective, the sintered Mo disks should have high theoretical densities and good dissolution rates. Therefore, it is important to continue the dissolution studies to optimize the disk-manufacturing process. 


\section{EXPERIMENTAL}

Sintered Mo disks were dissolved in 30\% hydrogen peroxide, which had been pre-heated to $70^{\circ} \mathrm{C}$. To that end, $12 \times 1 \mathrm{~mm}$ disks were dissolved in $40 \mathrm{~mL}$ of $\mathrm{H}_{2} \mathrm{O}_{2}$, while larger disks were dissolved in $80 \mathrm{~mL}$ of $\mathrm{H}_{2} \mathrm{O}_{2}$. The sintered Mo disks were provided by ORNL and were prepared from commercial natural Mo powders, Mo-100 enriched powder, and ANL-recycled $\mathrm{MoO}_{3}$ powders after reduction to Mo metal. 


\section{RESULTS AND DISCUSSION}

Table 1 summarizes the characterization data for Mo-100 enriched sintered disks. Disks were made from commercial as-received Mo metal powder or Mo metal from recycled $\mathrm{MoO}_{3}$ material after the reduction to Mo metal. Disks marked as recycle blend were made of $80 \%$ commercial as-received Mo powder and 20\% recycled Mo powder. Physical differences between powders can be seen in Figure 1. The particle shape for commercial as-received powders is more rounded while the recycled material exhibits sharper edges. The commercial powders sintered more easily than the recycled Mo powder. Dissolution rates varied in the range of 0.21-0.53 g/min and were mostly driven by the open porosity (Figure 2).

Table 2 compares the data for the disks made from recycled natural Mo and commercial NPA Mo powder. A significant difference in the open porosity dictates the dissolution rates. While the open porosity for the disks made from recycled Mo material and sintered at $1500-1600^{\circ} \mathrm{C}$ is very low (usually $<1 \%$ ), the open porosity of the NPA disks pressed under the same conditions (100 ksi) is $>8 \%$. There is not much difference in the dissolution rates for 0.5 -mm versus 1-mm thick disks made from the recycled material.

Interesting behavior was observed for the NPA disks pressed at 100 and $200 \mathrm{ksi}$. The green densities for the disks pressed at $100 \mathrm{ksi}$ were $\sim 82.5 \%$, and after sintering at $\sim 1500^{\circ} \mathrm{C}$, the densities increased to 89.5-91\%. On the other hand, the green density of the NPA disks pressed at $200 \mathrm{ksi}$ was $~ 92 \%$, and the final density of the sintered disks increased by only $\sim 1.5-1.8 \%$. The effect of sintering temperature $\left(1200^{\circ} \mathrm{C}\right.$ to $\left.1500^{\circ} \mathrm{C}\right)$ on the final open porosity of the NPA disks pressed at $200 \mathrm{ksi}$ was significant and had a major impact on the dissolution rates, as shown by Figure 3.

Figure 4 shows significant differences in the morphology of recovered Mo powder and commercial NPA Mo powder. In the recycled material, Mo particles coalesced together and formed larger particles; a lower open porosity is obvious even before pressing the powder into disks. The morphology of recycled ANL \#80 material is similar to that of the recycled Mo-100 powder (Figure 1). These two recycled $\mathrm{MoO}_{3}$ powders were products from small-scale recovery experiments, where $\mathrm{MoO}_{3}$ precipitate was dried in a beaker on a hot plate and then ground using a mortar and pestle. When NPA powder is pressed at $200 \mathrm{ksi}$ and sintered at $1400^{\circ} \mathrm{C}$ to $1500^{\circ} \mathrm{C}$, the open porosity is below $3 \%$, and the dissolution rates are low $(<0.35 \mathrm{~g} / \mathrm{min})$. On the other hand, when pressed at $100 \mathrm{ksi}$ and sintered at $1500^{\circ} \mathrm{C}$ to $1550^{\circ} \mathrm{C}$, the open porosity was still very high (8-9.5\%), and the dissolution rates were in the range of

2.4-2.7 g/min, about ten times higher than for the disk pressed at $200 \mathrm{ksi}$ and sintered at the same temperature.

Table 3 shows another set of disks made from the recycled $\mathrm{MoO}_{3}$ powder (ANL\#80) that was sintered at $1200^{\circ} \mathrm{C}-1500^{\circ} \mathrm{C}$ and pressed at $150-200 \mathrm{ksi}$. An increase in temperature from $1200^{\circ} \mathrm{C}$ to $1400^{\circ} \mathrm{C}$ (disks \#73 and \#74) reduces the open porosity from $11 \%$ to $1.6 \%$. When higher pressure at the same sintering temperature was applied, the open porosity was also reduced, as illustrated in Figure 5. 
TABLE 1 Characteristics of Sintered Mo-100 Enriched Disks and Corresponding Dissolution Rates

\begin{tabular}{|c|c|c|c|c|c|c|c|c|c|c|c|}
\hline \multirow[b]{2}{*}{$\#$} & \multirow[b]{2}{*}{ Type } & \multirow[b]{2}{*}{$\begin{array}{c}\text { Pressure, } \\
\text { ksi }\end{array}$} & \multirow[b]{2}{*}{$\begin{array}{c}\text { Green } \\
\text { Density, } \\
\% \\
\end{array}$} & \multicolumn{2}{|c|}{ Sintering ${ }^{\mathrm{a}}$} & \multirow[b]{2}{*}{$\begin{array}{c}\text { Sinter. } \\
\text { Density, } \\
\% \\
\end{array}$} & \multirow[b]{2}{*}{$\begin{array}{c}\text { Open } \\
\text { Porosity, } \\
\% \\
\end{array}$} & \multirow[b]{2}{*}{$\begin{array}{c}\text { Diameter, } \\
\mathrm{mm}\end{array}$} & \multirow[b]{2}{*}{$\begin{array}{c}\text { Thickness, } \\
\text { mm }\end{array}$} & \multirow[b]{2}{*}{$\begin{array}{c}\text { Mass, } \\
\mathrm{g}\end{array}$} & \multirow[b]{2}{*}{$\begin{array}{c}\text { Diss. Rate, } \\
\text { g/min }\end{array}$} \\
\hline & & & & $\begin{array}{c}\text { Temp., } \\
{ }^{\circ} \mathrm{C} \\
\end{array}$ & $\begin{array}{c}\text { Time, } \\
\mathrm{hr}\end{array}$ & & & & & & \\
\hline 47 & As-received & 100 & 68.9 & 1400 & 1 & 89.7 & 8.2 & 11.56 & 0.99 & 0.98 & 0.43 \\
\hline 48 & As-received & 100 & 69.2 & 1500 & 1 & 93.3 & 0.4 & 11.35 & 1.01 & 1.00 & 0.22 \\
\hline 49 & As-received & 100 & 73.4 & $1400 / 1500$ & $1 / 1$ & 83.7/89.1 & 15.6/8.2 & 11.88 & 0.93 & 0.95 & 0.53 \\
\hline 50 & Recycled & 100 & 70.8 & $1400 / 1500$ & $1 / 1$ & $88.2 / 94.0$ & $7.4 / 0.4$ & 10.84 & 1.08 & 0.99 & 0.24 \\
\hline 51 & Recycle blend & 100 & 69.3 & $1400 / 1500$ & $1 / 1$ & $89.7 / 93.8$ & $8.4 / 0.7$ & 11.39 & 0.96 & 0.95 & 0.25 \\
\hline 52 & Recycle blend & 100 & 73.4 & $1400 / 1500$ & $1 / 1$ & $84.9 / 90.1$ & 13.7/5.6 & 11.76 & 0.95 & 0.97 & 0.43 \\
\hline
\end{tabular}

a Disks sintered under $\mathrm{Ar} / 4 \% \mathrm{H}_{2}$ atmosphere. 

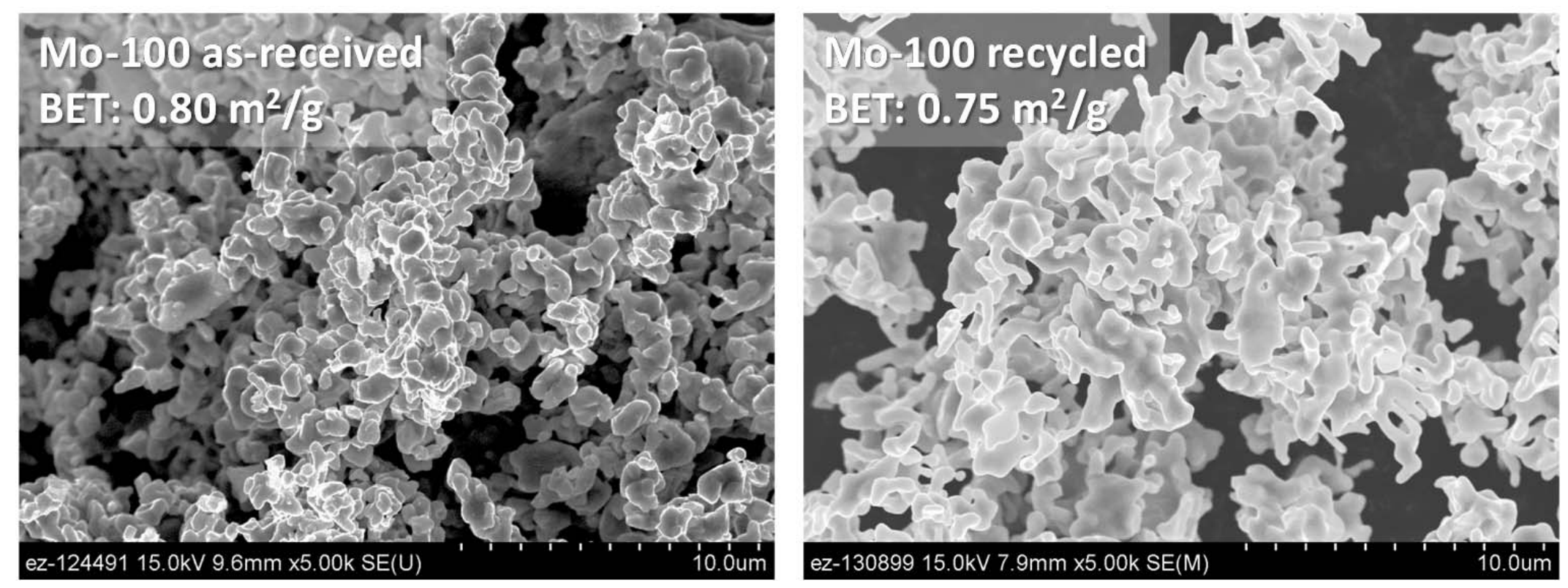

FIGURE 1 SEM Images of As-Received Mo-100 Enriched Powder (Left) and Recycled Mo-100 Enriched Powder (Right). SEM images provided by Steve Nunn (ORNL). 


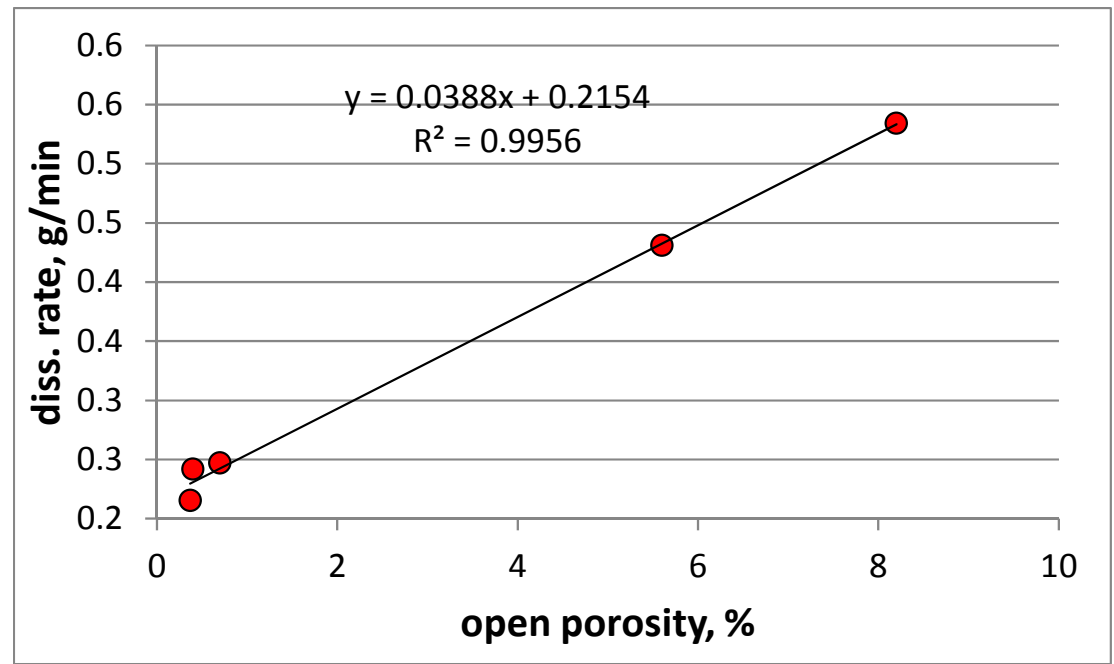

FIGURE 2 Dissolution Rates of Mo-100 Disks Sintered at $1500^{\circ} \mathrm{C}$ versus Open Porosity

Another set of disks was made from a commercial PM Mo powder that had been spray dried. The particle size of spray-dried spheres was in the range of 45 to $90 \mu \mathrm{m}$. The spray-dried spheres were made of $\sim 5 \mu \mathrm{m}$ Mo powder particles that were glued together and then heated to remove the binder and partially sintered. An SEM image of the spray-dried PM Mo powder is compared to that of NPA powder in Figure 6.

Table 4 shows the characteristics of PM Mo disks together with their dissolution rates. Dissolution rates for all PM disks were very high (1.78-3.14 g/min), but several features about these disks should be discussed. Figure 7 shows the temperature profile during dissolution of the disks.

The temperature of the $\mathrm{H}_{2} \mathrm{O}_{2}$ solution for disks \#83-85 increased rapidly ( $30^{\circ} \mathrm{C}$ in $\sim 20 \mathrm{~s}$ ), significantly faster than that for disk \#82 ( 40 s), which is a common heating rate during dissolution of the majority of the sintered Mo disks. The dissolution reaction for disks \#83-85 was vigorous, causing a large amount of splattering. A significant amount of steam was produced during this exothermic reaction, where $\mathrm{H}_{2} \mathrm{O}_{2}$ was decomposed into water vapor. Although complete dissolution occurred in about 60-70 s, a significant amount of $\mathrm{H}_{2} \mathrm{O}_{2}$ was consumed (determined by a difference in volume), with consumption rates of $35 \mathrm{~mL} \mathrm{H}_{2} \mathrm{O}_{2}$ per minute. This is significant, and it is not the preferred dissolution behavior for processing large quantities of Mo (production-size irradiated target with 300-600 g of Mo). Good dissolution rates in the range of 1.9-2.9 g/min were observed for disks \#81, \#82, and \#86-88 but with significantly lower consumptions of $\mathrm{H}_{2} \mathrm{O}_{2}$ (6-15 mL). This result is promising, but dissolution studies with more disks need to be performed to investigate the behavior of spray-dried Mo disks. 


\section{TABLE 2 Characteristics of Sintered Mo-100 Enriched Disks and Corresponding Dissolution Rates}

\begin{tabular}{|c|c|c|c|c|c|c|c|c|c|c|c|}
\hline \multirow[b]{2}{*}{$\#$} & \multirow[b]{2}{*}{ Type } & \multirow[b]{2}{*}{$\begin{array}{c}\text { Pressure, } \\
\text { ksi }\end{array}$} & \multirow{2}{*}{$\begin{array}{c}\text { Green } \\
\text { Density, } \\
\%\end{array}$} & \multicolumn{2}{|c|}{ Sintering ${ }^{\mathrm{a}}$} & \multirow{2}{*}{$\begin{array}{c}\text { Sinter. } \\
\text { Density, } \\
\% \\
\end{array}$} & \multirow{2}{*}{$\begin{array}{c}\text { Open } \\
\text { Porosity, } \\
\% \\
\end{array}$} & \multirow[b]{2}{*}{$\begin{array}{c}\text { Diameter, } \\
\text { mm }\end{array}$} & \multirow[b]{2}{*}{$\begin{array}{c}\text { Thickness } \\
\text {, mm }\end{array}$} & \multirow[b]{2}{*}{$\begin{array}{c}\text { Mass, } \\
\text { g }\end{array}$} & \multirow[b]{2}{*}{$\begin{array}{c}\text { Diss. Rate } \\
\text { g/min }\end{array}$} \\
\hline & & & & $\begin{array}{c}\text { Temp., } \\
{ }^{\circ} \mathrm{C} \\
\end{array}$ & $\begin{array}{c}\text { Time, } \\
\text { hr }\end{array}$ & & & & & & \\
\hline 53 & Recycled ANL\#80 & 100 & 75.3 & $1300 / 1600$ & $1 / 1$ & 85.8/91.4 & $11.4 / 0$ & 11.9 & 0.98 & 1.0 & 0.14 \\
\hline 54 & Recycled ANL\#80 & 100 & 76.3 & $1300 / 1600$ & $1 / 1$ & $87.2 / 90.8$ & $10.5 / 0$ & 11.9 & 0.53 & 0.50 & 0.13 \\
\hline 55 & Recycled ANL\#80 & 100 & 75.3 & $1400 / 1600$ & $1 / 1$ & 86.9/91.7 & $6.4 / 0.12$ & 11.8 & 1.00 & 1.0 & 0.18 \\
\hline 56 & Recycled ANL\#80 & 100 & 75.7 & $1400 / 1600$ & $1 / 1$ & 87.9/91.5 & $8.4 / 0$ & 11.8 & 0.52 & 0.50 & 0.18 \\
\hline 57 & Recycled ANL\#80 & 100 & 75.0 & 1500 & 1 & 89.1 & 1.5 & 11.9 & 1.00 & 1.01 & 0.34 \\
\hline 58 & Recycled ANL\#80 & 100 & 76.3 & 1500 & 1 & 88.5 & 4.8 & 11.9 & 0.50 & 0.50 & 0.31 \\
\hline 59 & Recycled ANL\#80 & 100 & 76.1 & $1500 / 1600$ & $1 / 1$ & 88.6/91.5 & $5.4 / 0.1$ & 11.9 & 1.01 & 1.02 & 0.19 \\
\hline 60 & Recycled ANL\#80 & 100 & 77.4 & $1500 / 1600$ & $1 / 1$ & 87.8/91.1 & $9.3 / 0.5$ & 11.9 & 0.54 & 0.50 & 0.13 \\
\hline 61 & Recycled ANL\#80 & 100 & 75.5 & 1600 & 1 & 92.2 & 0.2 & 11.8 & 0.99 & 1.0 & 0.22 \\
\hline 62 & Recycled ANL\#80 & 100 & 77.0 & 1600 & 1 & 92.5 & 0.0 & 11.8 & 0.51 & 0.50 & 0.18 \\
\hline 63 & Climax NPA & 100 & 82.6 & 1500 & 1 & 89.5 & 9.4 & 32.2 & 0.57 & 4.04 & 2.43 \\
\hline 64 & Climax NPA & 100 & 82.2 & 1500 & 2 & 89.9 & 9.5 & 32.2 & 0.57 & 4.05 & 2.70 \\
\hline 65 & Climax NPA & 100 & 82.5 & $1500 / 1550$ & $1 / 1$ & 88.9/90.9 & 10.6/8.0 & 32.0 & 0.57 & 4.03 & 2.69 \\
\hline 66 & Climax NPA & 100 & 82.4 & 1550 & 1 & 90.4 & 9.0 & 32.0 & 0.57 & 4.02 & 2.54 \\
\hline 67 & Climax NPA & 200 & 91.9 & 1200 & 1 & 93.5 & 4.9 & 32.8 & 0.51 & 3.91 & 1.02 \\
\hline 68 & Climax NPA & 200 & 92.3 & 1300 & 1 & 93.8 & 4.0 & 32.9 & 0.52 & 3.93 & 0.54 \\
\hline 69 & Climax NPA & 200 & 92.7 & 1400 & 1 & 94.2 & 2.8 & 32.6 & 0.52 & 3.92 & 0.35 \\
\hline 70 & Climax NPA & 200 & 92.4 & 1500 & 1 & 94.2 & 0.5 & 32.7 & 0.54 & 3.94 & 0.25 \\
\hline
\end{tabular}

a Disks \#53-62 were sintered under $\mathrm{Ar} / 4 \% \mathrm{H}_{2}$ atmosphere, and disks \#63-70 were sintered under Ar/7\% $\mathrm{H}_{2}$ atmosphere. 


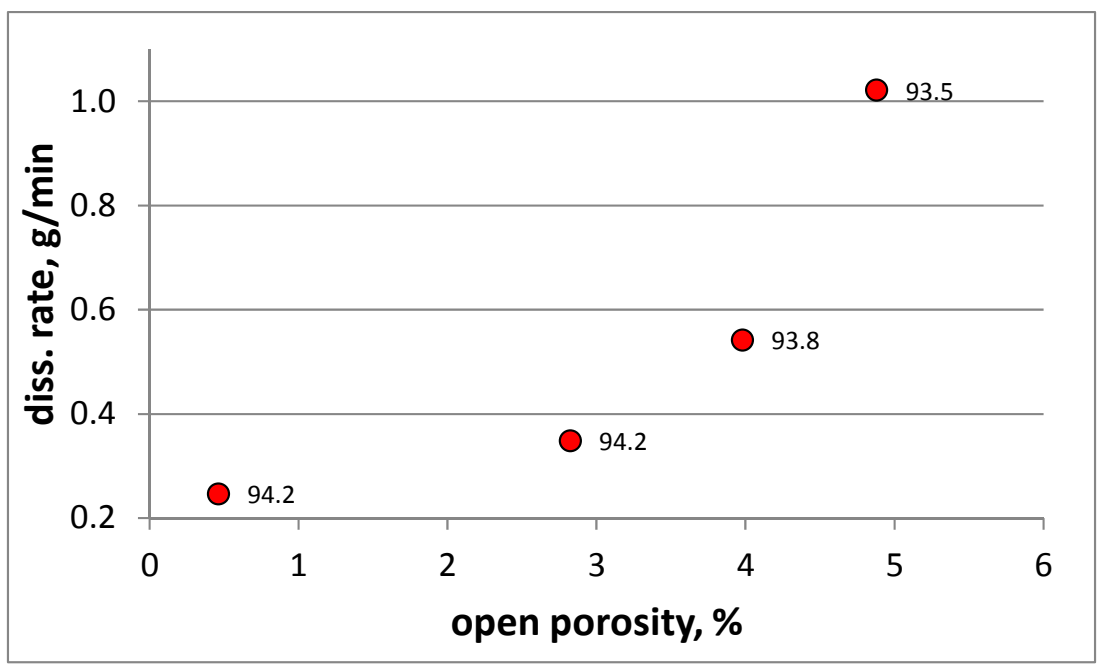

FIGURE 3 Dissolution Rates of NPA Mo Disks (pressed at 200 ksi, sintered at $1200-1500^{\circ} \mathrm{C}$ ) versus Open Porosity. Numbers next to the symbol show the densities of sintered disks in percent.
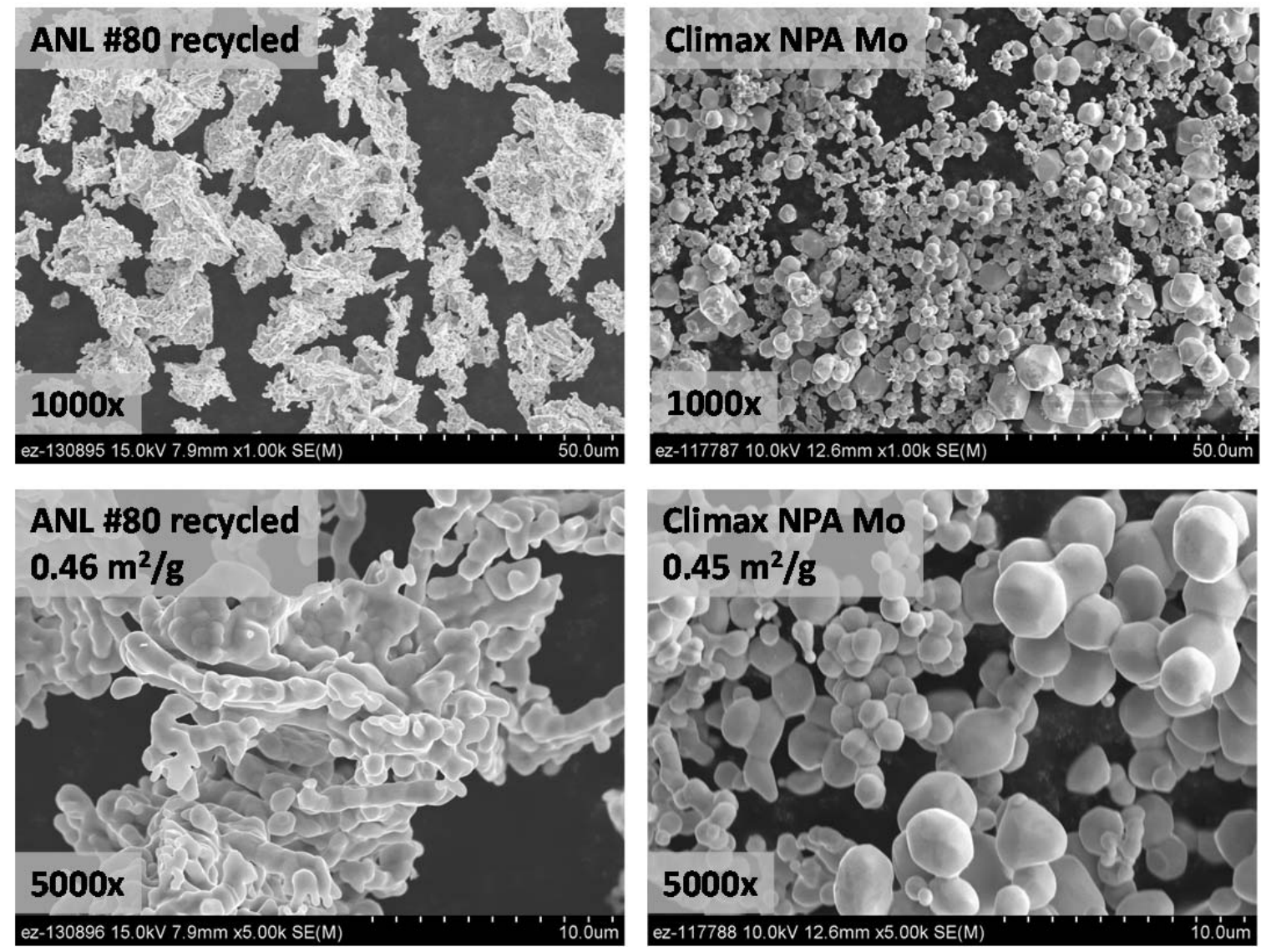

FIGURE 4 SEM Images of Mo Powder Obtained after the Reduction of Recycled ANL\#80 $\mathrm{MoO}_{3}$ Powder and Commercial NPA Mo Powder. SEM images provided by Steve Nunn (ORNL). 


\section{TABLE 3 Characteristics of Mo Disks from Recycled ANL\#80 $\mathrm{MoO}_{3}$ and Corresponding Dissolution Rates}

\begin{tabular}{|c|c|c|c|c|c|c|c|c|c|c|c|}
\hline \multirow[b]{2}{*}{$\#$} & \multirow[b]{2}{*}{ Type } & \multirow[b]{2}{*}{$\begin{array}{c}\text { Pressure, } \\
\text { ksi }\end{array}$} & \multirow{2}{*}{$\begin{array}{c}\text { Green } \\
\text { Density, } \\
\% \\
\end{array}$} & \multicolumn{2}{|c|}{ Sintering ${ }^{\mathrm{a}}$} & \multirow{2}{*}{$\begin{array}{c}\text { Sinter. } \\
\text { Density, } \\
\% \\
\end{array}$} & \multirow{2}{*}{$\begin{array}{c}\text { Open } \\
\text { Porosity, } \\
\% \\
\end{array}$} & \multirow[b]{2}{*}{$\begin{array}{c}\text { Diameter, } \\
\mathrm{mm}\end{array}$} & \multirow[b]{2}{*}{$\begin{array}{c}\text { Thickness, } \\
\text { mm }\end{array}$} & \multirow[b]{2}{*}{$\begin{array}{c}\text { Mass, } \\
\mathrm{g}\end{array}$} & \multirow[b]{2}{*}{$\begin{array}{c}\text { Diss. Rate, } \\
\text { g/min }\end{array}$} \\
\hline & & & & $\begin{array}{c}\text { Temp., } \\
{ }^{\circ} \mathrm{C} \\
\end{array}$ & $\begin{array}{c}\text { Time, } \\
\text { hr }\end{array}$ & & & & & & \\
\hline 73 & Recycled ANL\#80 & 150 & 83.5 & 1200 & 1 & 87.8 & 11.0 & 12.5 & 0.90 & 0.98 & 0.45 \\
\hline 74 & Recycled ANL\#80 & 150 & 83.7 & 1400 & 1 & 90.6 & 1.6 & 12.3 & 0.93 & 1.03 & 0.27 \\
\hline 75 & Recycled ANL\#80 & 150 & 83.8 & 1500 & 1 & 91.8 & 0.8 & 12.3 & 0.91 & 1.00 & 0.18 \\
\hline 76 & Recycled ANL\#80 & 200 & 88.2 & 1200 & 1 & 90.1 & 6.9 & 12.6 & 0.80 & 0.91 & 0.44 \\
\hline 77 & Recycled ANL\#80 & 200 & 88.4 & 1300 & 1 & 91.8 & 3.6 & 12.5 & 0.86 & 0.99 & 0.33 \\
\hline 78 & Recycled ANL\#80 & 200 & 88.6 & 1400 & 1 & 92.9 & 0.5 & 12.5 & 0.88 & 1.00 & 0.27 \\
\hline 79 & Climax NPA & 150 & 90.0 & 1200 & 1 & 91.2 & 8.5 & 32.6 & 0.54 & 3.92 & 2.24 \\
\hline
\end{tabular}

a The disks were sintered under Ar/4\% H2 atmosphere, except NPA disk that was sintered under Ar/7\% H2 atmosphere. 


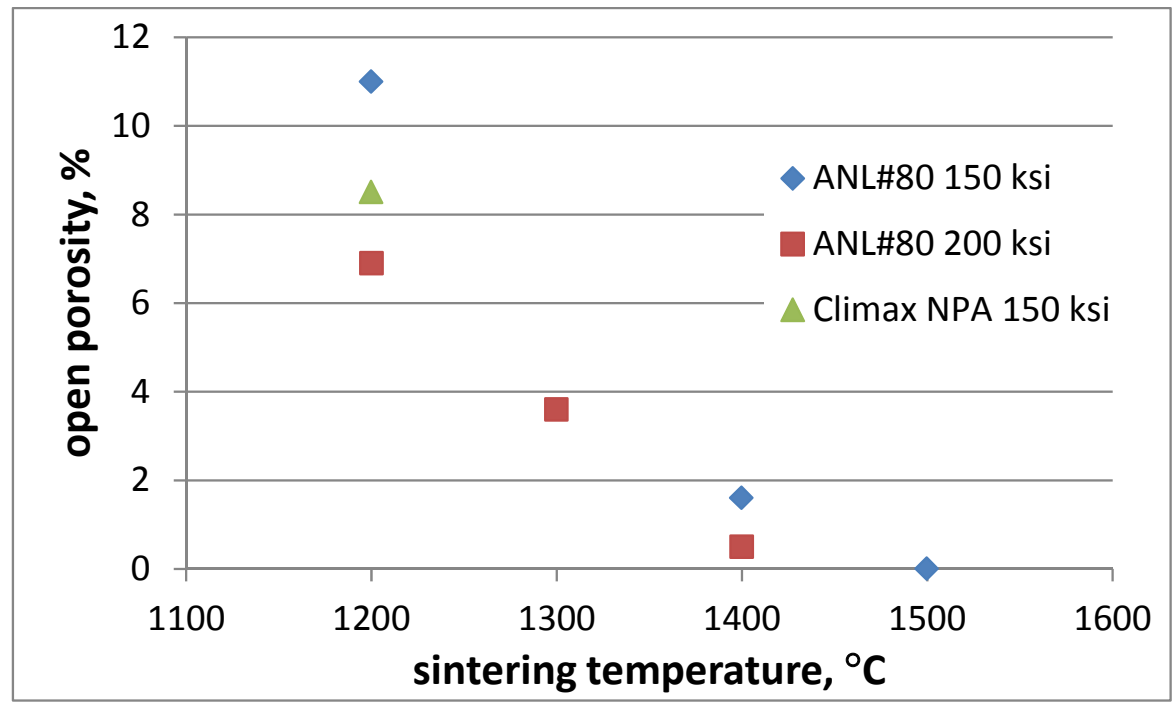

FIGURE 5 Effect of Sintering Temperature and Pressing on Open Porosity of Disks Made from Recycled ANL\#80 $\mathrm{MoO}_{3}$ Powder
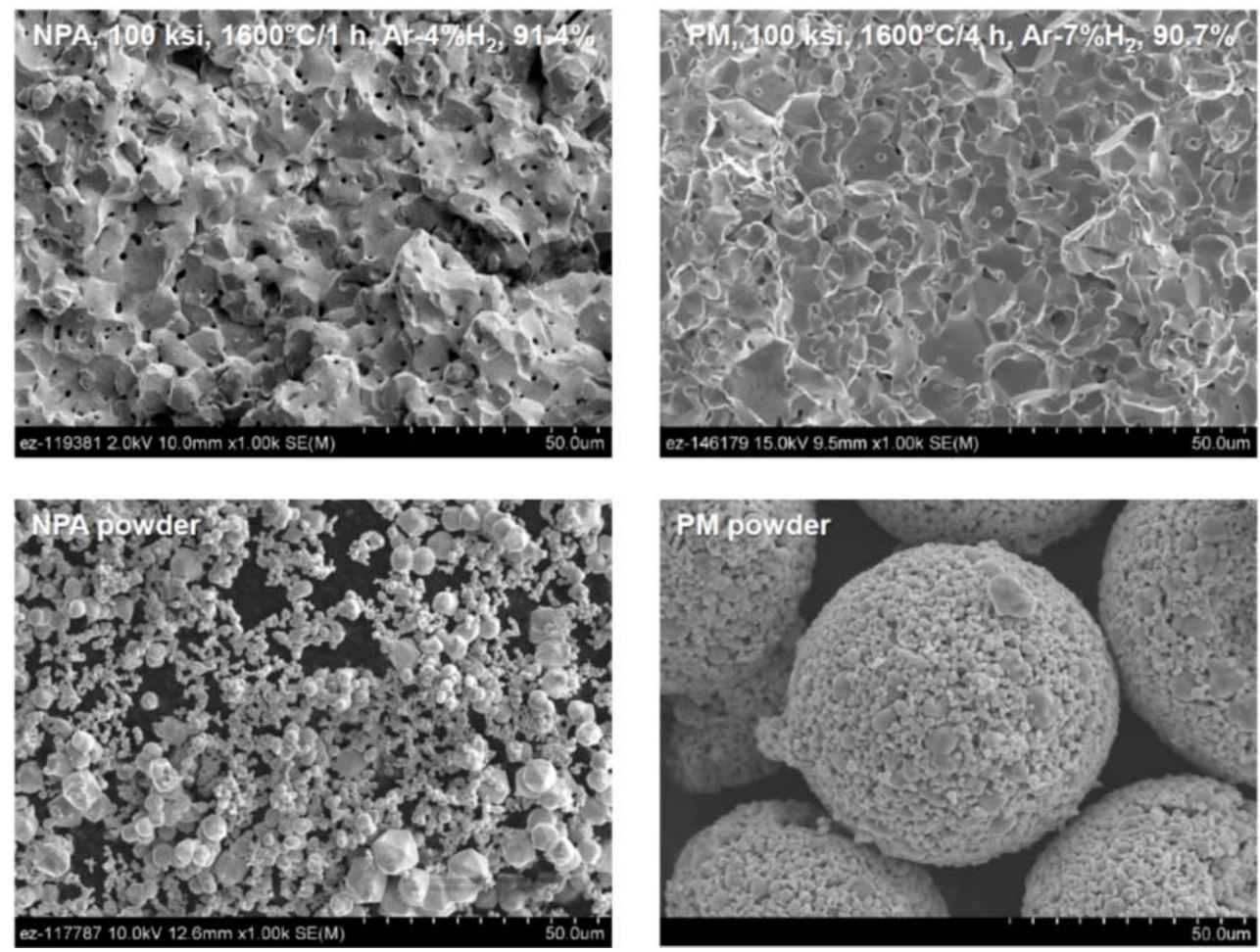

FIGURE 6 SEM Images of Sintered Disks Fracture and Starting Powders for NPA and PM Disks. SEM images were provided by Rick Lowden (ORNL). SEM image of PM powder was obtained from the Climax Mo Powder Product Sheet. 
TABLE 4 Characteristics of Sintered Mo Disks Made from Commercial PMA Spray-Dried Mo Spheres and Corresponding Dissolution Rates ${ }^{\mathrm{a}}$

\begin{tabular}{|c|c|c|c|c|c|c|c|c|c|c|c|}
\hline$\#$ & Type & $\begin{array}{l}\text { Pressure, } \\
\text { ksi }\end{array}$ & $\begin{array}{c}\text { Green } \\
\text { Density, } \\
\% \\
\end{array}$ & $\begin{array}{c}\text { Sinter. } \\
\text { Density, } \\
\% \\
\end{array}$ & $\begin{array}{c}\text { Open } \\
\text { Porosity, } \\
\% \\
\end{array}$ & $\begin{array}{c}\text { Diameter, } \\
\text { mm }\end{array}$ & $\begin{array}{c}\text { Thickness, } \\
\text { mm }\end{array}$ & $\begin{array}{c}\text { Mass, } \\
\mathrm{g}\end{array}$ & $\begin{array}{l}\text { Diss. } \\
\text { Rate, } \\
\text { g/min }\end{array}$ & $\begin{array}{c}\mathrm{H}_{2} \mathrm{O}_{2} \text { Spent, } \\
\mathrm{mL}\end{array}$ & $\begin{array}{c}\text { Diss. Rate } \\
\text { per } \mathrm{mL} \mathrm{H}_{2} \mathrm{O}_{2} \text {, } \\
\mathrm{g} / \mathrm{min} / \mathrm{mL}\end{array}$ \\
\hline 80 & Climax PMA & 100 & 77.4 & 90.3 & 6.4 & 28.8 & 0.53 & 3.09 & 1.78 & 25 & 0.07 \\
\hline 81 & Climax PMA & 100 & 77.1 & 90.6 & 6.3 & 28.8 & 0.53 & 3.13 & 1.97 & 6 & 0.33 \\
\hline 82 & Climax PMA & 100 & 77.8 & 90.5 & 6.5 & 28.7 & 0.53 & 3.10 & 1.86 & 10 & 0.19 \\
\hline 83 & Climax PMA & 100 & 76.3 & 90.1 & 7.8 & 28.9 & 0.52 & 3.11 & 2.66 & 35 & 0.08 \\
\hline 84 & Climax PMA & 100 & 76.9 & 89.3 & 8.2 & 28.9 & 0.52 & 3.12 & 2.88 & 38 & 0.08 \\
\hline 85 & Climax PMA & 100 & 77.0 & 89.1 & 8.4 & 28.9 & 0.53 & 3.14 & 3.14 & 30 & 0.10 \\
\hline 86 & Climax PMA & 100 & 76.2 & 89.9 & 7.6 & 28.7 & 0.52 & 3.07 & 2.17 & 15 & 0.14 \\
\hline 87 & Climax PMA & 100 & 76.2 & 89.6 & 8.3 & 28.7 & 0.53 & 3.10 & 2.33 & 13 & 0.18 \\
\hline 88 & Climax PMA & 100 & 76.7 & 90.2 & 8.2 & 28.7 & 0.53 & 3.08 & 2.85 & 11 & 0.26 \\
\hline
\end{tabular}

a The disks were sintered under $\mathrm{Ar} / 7 \% \mathrm{H}_{2}$ atmosphere at $1600^{\circ} \mathrm{C}$ for 4 hours. 


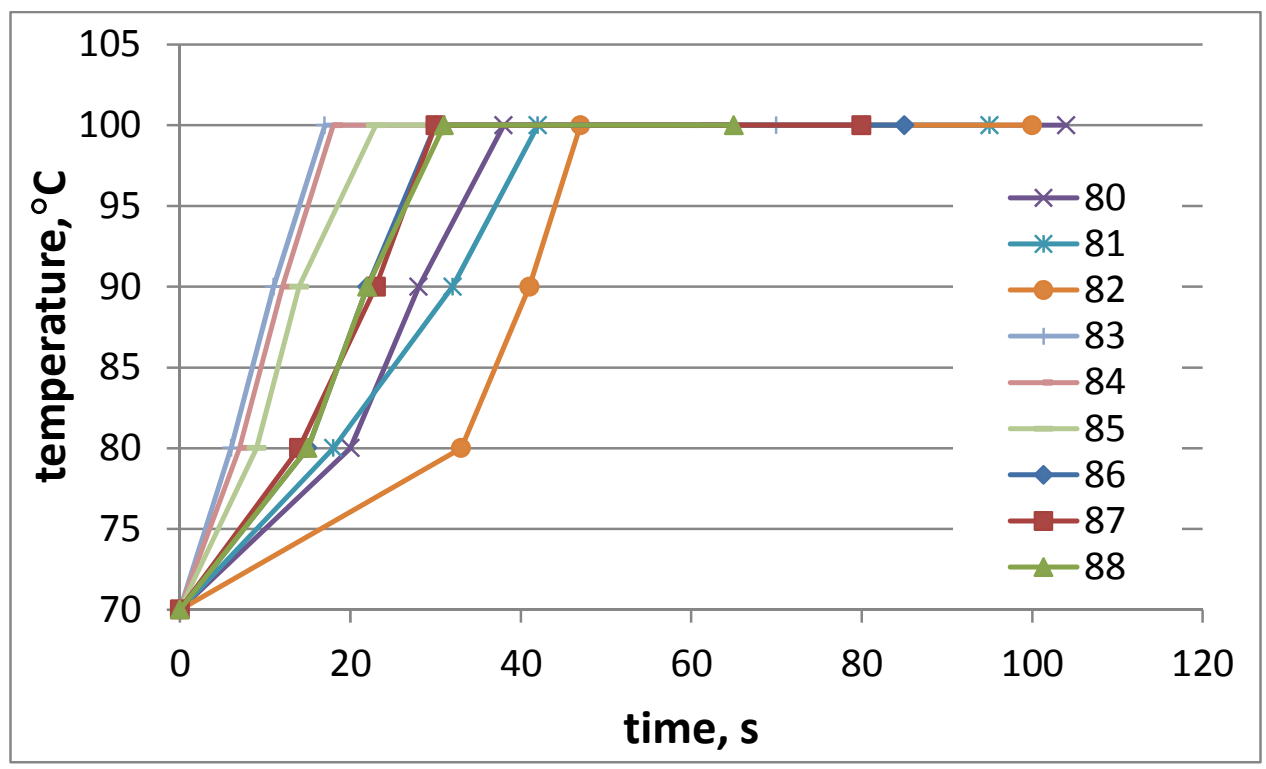

FIGURE 7 Temperature Profile during the Dissolution of PM Mo Disks

Data about the last set of sintered disks received from ORNL, including the dissolution rate, are listed in Table 5. Noticeable differences in the disk diameter between recycled and commercial Mo powders are due to the increased shrinking of disks made from the recycled material. This recycled $\mathrm{MoO}_{3}$ powder was a product of a large-scale recovery experiment, where a final $\mathrm{MoO}_{3}$ precipitate was dried in an oven at $160^{\circ} \mathrm{C}$ and then ground using an electric mill. Another noticeable difference was the density after sintering. While the NPA disks had densities in the range of 90.2-91.4\%, the disks made from recycled material have densities in the range of 96.7-97.5\% for the same sintering conditions. This difference was due to the size of the recycled Mo powder particles. The SEM images in Figure 8 show a significant difference in the size of the starting Mo powders.

We found that the particle size of the Mo powder may depend on the mass of $\mathrm{MoO}_{3}$ used for the reduction process. The composition of the atmosphere, especially the water content, can also affect the size of the reduced Mo particles. For the smaller batch size ( $30 \mathrm{~g})$, the gas diffusion and water removal in and out of the bed are more rapid. Increasing the batch size to 500-1000 g leads to the production of Mo powder with a larger particle size, which is more comparable to the particle size of the commercial NPA powder. As expected, the dissolution rates for NPA disks were high (1.25-1.56 g/min) but were significantly lower than those for NPA disks \#63-66 (Table 2) sintered at the same temperature. This result is most likely due to the lower open porosity of the disks (\#92-94). On the other hand, one would expect a low dissolution rate for the disks made from ANL recycled $\mathrm{MoO}_{3}$ powder (\#89-91) because of the very high packing densities (96.7-97.5\%) and very low open porosity (0.24-0.32\%). Surprisingly, the dissolution rates were extremely high $(0.59-0.6 \mathrm{~g} / \mathrm{min})$ for such dense disks. This finding could be attributed to their grainy surface (Figure 9), which is due to the sintering properties of the powder composed of large agglomerates, ten to hundreds of microns (Figure 8). 
TABLE 5 Characteristics of Sintered Mo Disks Made from Recycled $\mathrm{MoO}_{3}$ Powder and Commercial NPA Powder

\begin{tabular}{|c|c|c|c|c|c|c|c|c|c|c|c|}
\hline \multirow[b]{2}{*}{$\#$} & \multirow[b]{2}{*}{ Type } & \multirow[b]{2}{*}{$\begin{array}{c}\text { Pressure, } \\
\text { ksi }\end{array}$} & \multirow[b]{2}{*}{$\begin{array}{c}\text { Green } \\
\text { Density, } \\
\% \\
\end{array}$} & \multicolumn{2}{|c|}{ Sintering $^{\mathrm{a}}$} & \multirow[b]{2}{*}{$\begin{array}{c}\text { Sinter. } \\
\text { Density, } \\
\% \\
\end{array}$} & \multirow[b]{2}{*}{$\begin{array}{c}\text { Open } \\
\text { Porosity, } \\
\% \\
\end{array}$} & \multirow[b]{2}{*}{$\begin{array}{c}\text { Diameter, } \\
\mathrm{mm}\end{array}$} & \multirow[b]{2}{*}{$\begin{array}{c}\text { Thickness, } \\
\text { mm }\end{array}$} & \multirow[b]{2}{*}{$\begin{array}{c}\text { Mass, } \\
\mathrm{g}\end{array}$} & \multirow[b]{2}{*}{$\begin{array}{c}\text { Diss. Rate } \\
\mathrm{g} / \mathrm{min}\end{array}$} \\
\hline & & & & $\begin{array}{c}\text { Temp., } \\
{ }^{\circ} \mathrm{C}\end{array}$ & $\begin{array}{c}\text { Time, } \\
\mathrm{hr}\end{array}$ & & & & & & \\
\hline 89 & ANL recycled $\mathrm{MoO}_{3}$ & 100 & 65.7 & 1500 & 1 & 97.5 & 0.32 & 26.7 & 0.58 & 3.14 & 0.59 \\
\hline 90 & ANL recycled $\mathrm{MoO}_{3}$ & 100 & 67.1 & 1500 & 1 & 97.3 & 0.24 & 26.7 & 0.56 & 3.10 & 0.60 \\
\hline 91 & ANL recycled $\mathrm{MoO}_{3}$ & 100 & 65.3 & 1500 & 1 & 96.7 & 0.32 & 26.7 & 0.57 & 3.10 & 0.59 \\
\hline 92 & Climax NPA & 100 & 78.8 & 1500 & 1 & 91.2 & 3.80 & 29.0 & 0.51 & 3.11 & 1.56 \\
\hline 93 & Climax NPA & 100 & 80 & 1500 & 1 & 90.2 & 4.10 & 28.9 & 0.51 & 3.15 & 1.26 \\
\hline 94 & Climax NPA & 100 & 81.6 & 1500 & 1 & 91.4 & 3.60 & 28.9 & 0.52 & 3.13 & 1.25 \\
\hline
\end{tabular}

a The disks were sintered under $\mathrm{Ar} / 7 \% \mathrm{H}_{2}$ atmosphere. 

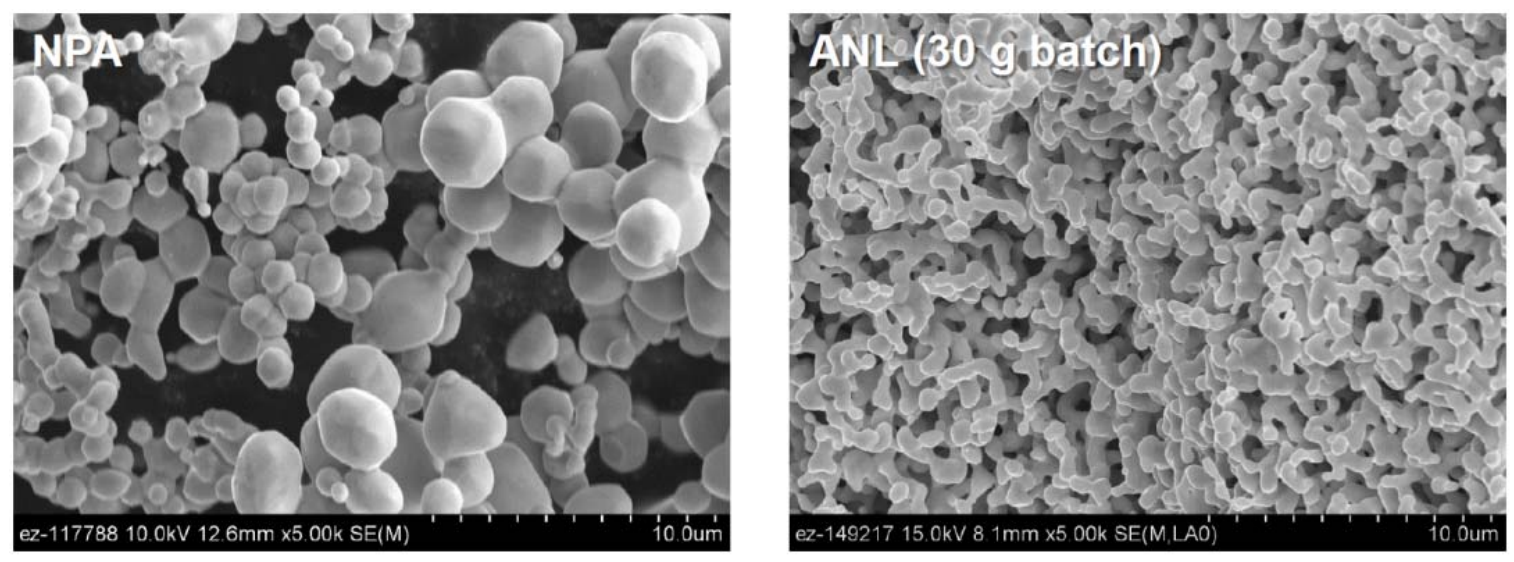

FIGURE 8 SEM Images of As-received Commercial NPA Powder and Reduced Small Batch (30 g) of ANL Recycled $\mathrm{MoO}_{3}$ Powder. SEM images provided by Rick Lowden (ORNL).

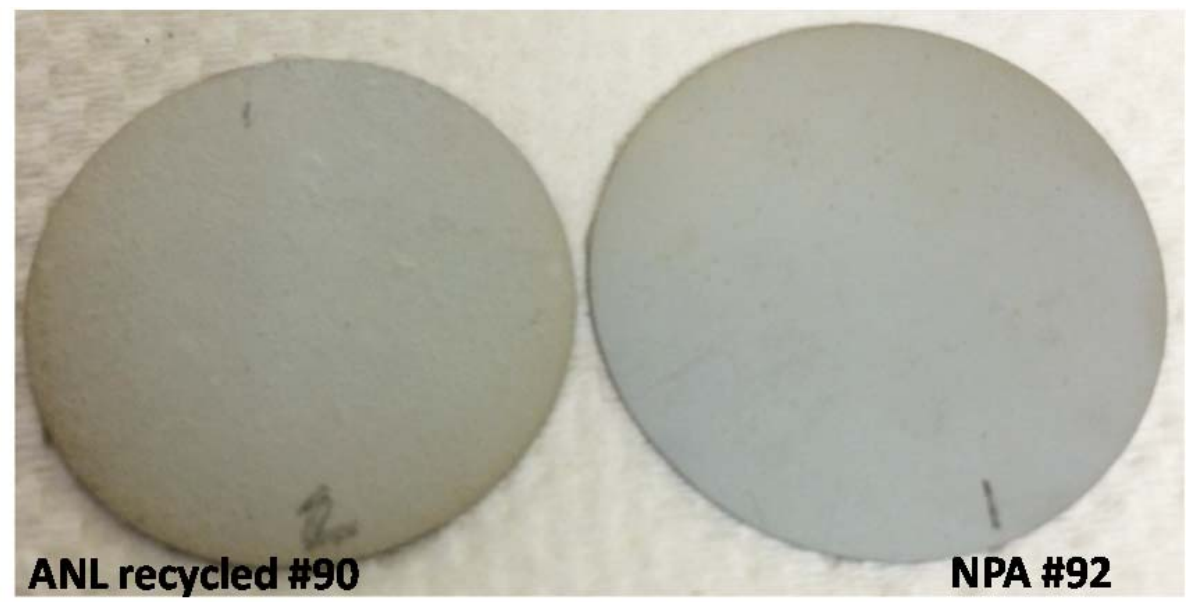

FIGURE 9 Photograph of Disk \#90 (Table 5) Made from ANLRecycled $\mathrm{MoO}_{3}$ Powder and NPA Disk \#92. The NPA disks had a noticeably smoother surface than the disks made from recycled material.

For future production of sintered disks made from recycled material, kilogram quantities of reduced Mo powder will need to be milled and then spray-dried. Nevertheless, the fast dissolution of dense disks made from large-scale recycled material is promising for future production of sintered disks. Several batches with kilogram quantities of ANL recycled $\mathrm{MoO}_{3}$ powder will be sent to ORNL next fiscal year to test the large-scale reduction process and production of sintered Mo disks from recycled material. 


\section{CONCLUSION}

Dissolution studies with disks prepared at ORNL revealed several new features that are important for the manufacturing of sintered Mo disks from recycled material for a production facility. The size of the $\mathrm{MoO}_{3}$ batch for the reduction can affect the particle size of Mo powder, and milling of the produced Mo powder may be required. Although the open porosities of the disks made from commercial powders were important for the dissolution kinetics, dissolution studies from large-scale recycled Mo material showed that even disks with very low open porosity $(<0.4 \%)$ and high packing densities ( $\sim 97 \%)$ can dissolve quickly $(0.6 \mathrm{~g} / \mathrm{min})$. Spraydried sintered Mo disks showed very high dissolution rates ( 2-3 g/min), but some disks dissolved so vigorously that the method would not be suitable for processing of production targets in a hot cell facility. However, spray-dried disks made from recycled Mo material should be explored further and in more detail next fiscal year. 
This page intentionally left blank 



\section{Argonne}

Chemical Sciences and Engineering Division

Argonne National Laboratory

9700 South Cass Avenue, Bldg. 205

Argonne, IL 60439-4837

www.anl.gov

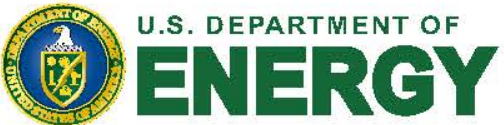

Argonne National Laboratory is a U.S. Department of Energy

laboratory managed by UChicago Argonne, LLC 